The Relative Earnings of Contingent Faculty in Higher Education

\author{
James Monks \\ Robins School of Business \\ University of Richmond, VA 23173 \\ jmonks@richmond.edu
}

December 2004 


\title{
The Relative Earnings of Contingent Faculty in Higher Education
}

\author{
Abstract \\ Part-time and full-time non-tenure track faculty currently represent almost \\ half of all faculty in U.S. higher education, yet little is known about their \\ earnings relative to tradition tenure-track faculty. This paper finds that \\ full-time non-tenure track faculty earn approximately 26 percent less per \\ hour from their academic institution and 18 percent less in total earnings \\ from all sources per hour than comparable tenure track assistant \\ professors. Part-time non-tenure track faculty earn 64 percent less per \\ hour from their institution, but only 1 percent less in total earnings per \\ hour than tenure track assistant professors.
}




\section{Introduction}

The past two decades have seen an increase in the use of temporary and part-time employees in the labor force. From 1973 to 1999, part-time employees (those working fewer than 35 hours a week) grew from 16.6 percent of the U.S. labor force to 24.1 percent. $^{1}$ The use of part-time employees in the private corporate sector of the economy is seen as a means of reducing labor costs and increasing the flexibility of managing the quasi-fixed portion of labor costs associated with hiring, training, and terminating employees. The increased use of temporary and part-time employees has also infiltrated the U.S. academic faculty labor market. In 1970, 22 percent of U.S. college and university faculty were considered by their institutions to be employed part-time. By 1997, 43 percent of faculty were employed part-time. $^{2}$

Higher education’s rigid tenure system provides greater motivation for hiring faculty outside of the tenure system as a means of affording institutions’ with heightened flexibility and greater long-term control over their labor costs. Clearly hiring part-time faculty to teach a limited number of classes per semester, or full-time faculty with fixed term contracts provides institutions with greater employment flexibility than hiring faculty into tenure track or tenured positions. Additionally, it is widely understood that not only do contingent faculty lower long term labor costs through greater flexibility of employment, but part-time and non-tenure track faculty are usually paid less than full-time tenure track faculty providing short term labor savings as well. While the increased use of part-time and non-tenure track faculty has been widely investigated (Ehrenberg and Klaff (2003); Longmate and Cosco (2002); Kosters and McCullough (1994); Lundy and Warme (1992)), little is known about the compensation of part-

${ }^{1}$ U.S. Bureau of Labor Statistics, Employment and Earnings, monthly, January issues.

${ }^{2}$ U.S. Department of Education, National Center for Education Statistics, Integrated Postsecondary Education Data System (IPEDS). Fall Staff Surveys. 
time and full-time non-tenure track faculty relative to their full-time tenure track counterparts beyond anecdotal evidence and institution specific policies. This study fills this void by examining the earnings of contingent faculty compared to tenure track faculty controlling for individual characteristics and institutional attributes using a nationally representative data set of faculty. Additionally, the data used in this paper allow for analyses of various measures of earnings both from the institution and from outside sources. The data also allow one to control for various measures of input including number of course sections taught and total hours worked. This allows for a more precise comparison of the earnings per unit of input of contingent faculty versus tenure track faculty. It is important to examine earnings per unit of input rather than total earnings as contingent faculty and part-time faculty by definition work fewer units of input than full-time tenure track faculty.

\section{Data}

The data used in this paper come from the National Center for Education Statistics’ National Study of Postsecondary Faculty (NSOPF), in 1999. This survey is designed to provide a nationally representative sample of faculty and instructional personnel throughout all sectors of higher education. The full sample contains responses from 18,043 individuals. The sample is restricted to focus on faculty whose primary activity is instruction for credit. The following restrictions are designed to provide a sample of full-time and contingent faculty with similar responsibilities in terms of teaching. The restrictions on the data set are intended to eliminate individuals whose primary activities are administration and research (see Table 1). The sample is first restricted by eliminating those individuals whose responses carry a sampling weight of zero because the respondents did not match the final sample criteria of the NCES (435); individuals who do not have faculty status (1269); do not have instructional duties for credit 
(1393); whose primary activity is not teaching (3439); did not teach at least one section but fewer than 12 sections in the preceding fall (508); employed at an institution that does not have a tenure system (1317); reported basic salary from their institution of less than $\$ 500$ or more than $\$ 300,000$ (65); and, reported that they usually worked 2 hours or less per week for their institution (111). The final restriction on the sample eliminated those individuals who began working for their institution in 1998 (1232). The questionnaire asked faculty in the spring of 1999 to report their salary from their institution for 1998. There is no way of knowing whether this salary represents a full calendar year's salary or employment at the institution for some portion of 1998 for faculty who began sometime in 1998. As a result, I limit the sample to those individuals who began their employment at their institution prior to 1998, so that I am reasonably certain that their reported salary represents a full calendar year's salary. This restriction will clearly eliminate part-time and full-time faculty who are most transient and tenure track faculty in the first year of their contract. This will most likely result in an understatement of the earnings differential between tenure track and contingent faculty.

Table 2 provides summary measures of selected variables used in the analysis. The resulting sample is composed of 54 percent full-time tenured or tenure track faculty, 8 percent full-time non-tenure track faculty, 36 percent part-time non-tenure track faculty, and 3 percent part-time tenured or tenure track faculty. The 39 percent part-time faculty in this sample is lower than the 43 percent part-time faculty reported in the overall sample and is the result of the restrictions outlined above. Additionally, the average age is approximately 50 years old. The sample is 61 percent male, 4 percent Hispanic, 5 percent African-American, and 4 percent Asian.

Twenty-one percent of the respondents work at research universities, 12 percent at doctoral universities, 26 percent at comprehensive institutions, 9 percent at baccalaureate colleges, 27 percent at two-year colleges, and 6 percent at specialized institutions. Additionally, 71 percent 
of the faculty in the sample report working at publicly controlled institutions, and 46 percent of the faculty report that there is a union or collective bargaining agent for full-time faculty at their institution (whether they are a member or not).

The average faculty member is a rather prolific researcher, although the median faculty member is not. For example, the average number of refereed journal articles is almost 10 articles published over one's career to date, but the median number of refereed journal articles is only one. Similarly, the median number of all other forms of research output (non-refereed articles, books and chapters, book reviews, and other scholarly output) is zero, with the exception of the median number of career presentations which is approximately 8 .

Table 3 presents summary measures of labor inputs and earnings by employment type (fulltime tenured or tenure track, full-time non-tenure track, part-time non-tenure track, and part-time tenure track). Full-time tenured or tenure track (henceforth referred to as tenure track) report working (both on paid and non-paid professional activities) 53 hours during a typical week in the fall of 1998. They also reported working for pay an average of 47.9 hours per week in total, and 45.5 hours per week for their institution. Full-time non-tenure track faculty reported working slightly less, both overall and for pay from their institution, than tenure track faculty. On the other hand, part-time faculty reported working on average 32.8 hours per week for pay, and only 13.6 hours per week for their institution. Part-time tenure track faculty reported working 32 hours per week overall, but only 22 hours per week for their institution, on average. All faculty were asked to report their employment for their academic employer through which the survey was sent in the event that they were working for more than one academic institution. While there is undoubtedly measurement error in the number of hours work, it is unlikely that this error is more prevalent in one category of employment than another. 
It is interesting to note the similarity in the percentage of time devoted to teaching across employment contracts. Full-time and part-time, tenure track and non-tenure track report spending between 62 and 72 percent of their time on teaching. The differences in time allocation lie in the percent of time devoted to research and other activities. Full-time tenure track faculty devote on average 13 percent of their time to research, although this will clearly vary across institutional type, while full-time non-tenure track and part-time non-tenure track devote on average 6 to 4 percent of their time to research, respectively. On the other hand, full-time tenure track and full-time non-tenure track allocate 7 to 9 percent of their time to other activities, while part-time non-tenure track spend 26 percent of their time on other activities, and part-time tenure track spend 12 percent of their time on other activities. It appears that full-time faculty devote almost all of their time to the activities for their institution (teaching, research, and service), while part-time faculty allocate a significant portion of their time to other activities, presumably work outside of academia. Similarly, full-time faculty teach approximately 7 sections per year, while part-time faculty teach on average just fewer than 5 sections per year. ${ }^{3}$

Despite eliminating faculty who reported basic salary greater than $\$ 300,000$, the earnings data are skewed to the right. Earnings measures per hour are particularly skewed to the right. As a result mean and median measures of earnings are in some cases dramatically different. Median earnings measures are reported in Table 3 and the natural log of earnings are used in the regression analyses to transform the earnings measures into data that more closely approximate a normal distribution.

There a number of ways that earnings can be measured across employment categories. First, total earnings from all sources can be examined. Full-time tenure track faculty had median

\footnotetext{
3 Respondents were asked how many class sections they taught in the fall of 1998 . The number of class sections taught per year is assumed to be 2 times the number taught in the fall.
} 
earnings from all sources of $\$ 64,130$ for $1998 .{ }^{4}$ The median full-time non-tenure track faculty earned $\$ 45,652$ in 1998 . Part-time non-tenure track earned a median of $\$ 37,337$, and part-time tenure track faculty had median earnings of $\$ 50,848$, in 1998 . Larger differences across employment categories come from comparing earnings from one's institution. Full-time tenure track faculty had total institutional earnings of $\$ 59,783$ and basic institutional earnings (this excludes earnings from stipends, grants, and overload courses outside of one's normal contract) of $\$ 54,978$. Institutional earnings represent 93 percent of total earnings and basic institutional earnings represent 86 percent of total earnings for the median full-time tenure track faculty. The median full-time non-tenure track faculty earns $\$ 45,652$ per year in total earnings, $\$ 41,304$ from her institution, and \$39,130 in basic salary. This represents 90 and 86 percent of total earnings, respectively.

The earnings of part-time faculty are substantially different from the earnings of full-time faculty. The median part-time non-tenure track faculty earns $\$ 37,337$ in total earnings but only $\$ 8,696$ from her institution, with $\$ 7,826$ in basic institutional earnings. Total and basic institutional earnings account for only 23 and 21 percent of total earnings, respectively. Parttime non-tenure track faculty earn a majority of their salary outside of their institutions. Parttime tenure faculty have median total earnings of $\$ 50,848$, and total institutional and basic institutional earnings of $\$ 21,739$, or 43 percent of total earnings.

The above values reflect earnings from one's institution and do not include fringe benefits. Because part-time and non-tenure track faculty often do not receive benefits or at least receive fewer and less generous benefits than full-time tenure track faculty, the total differences in compensation, including fringe benefits, between tenure track and contingent faculty are likely to be even greater than those outlined above.

${ }^{4}$ All dollar values are in 2001 CPI-U adjusted dollars. 
These total earnings and institutional earnings levels do not account for the significant differences in inputs across full-time and part-time faculty in terms of the number of sections taught and the number of hours worked in total and for one's institution. If one looks at basic institutional earnings per class section taught there remain substantial differences in earnings across employment categories. The median full-time tenure track faculty is paid $\$ 8,424$ per section; the median full-time non-tenure track faculty is paid $\$ 5,435$ per section; the median parttime non-tenure track faculty is paid $\$ 2,174$ per section; and the median part-time tenure track faculty member is paid $\$ 5,435$ per section.

Many tenure track faculty would argue that they are compensated only in part for teaching so that compensation per class section is not the relevant metric. Alternatively, I will now examine the median total institutional compensation per hour. Respondents were asked how many hours per week they usually worked for their institution in the fall of 1998 . Total annuals hours are assumed to equal the reported hours usually worked per week times 52 . This assumption may overstate the number of annual hours worked by contingent faculty if they are less likely to work for the institution during the summer than tenure track faculty. Alternatively, an arbitrary and subjective assumption about the annual hours of contingent faculty, both fulltime and part-time would be required. The median full-time tenure track faculty was paid $\$ 26.13$ per hour by her institution. The median full-time non-tenure track faculty was paid \$19.11 per hour by her institution, or 27 percent less. The median part-time non-tenure track faculty was paid \$15.68 per hour, or 40 percent less per hour. Part-time tenure track where paid $\$ 25.08$ per hour, or 4 percent less than full-time tenure track faculty.

What is perhaps most surprising are the differences in total earnings per hour across employment categories. The median full-time tenure track faculty had total earnings from all sources of $\$ 26.48$ per hour. The median full-time non-tenure track faculty had total earnings of 
\$19.11 per hour, or 28 percent less than the median full-time tenure track faculty. Part-time nontenure track faculty had median total earnings per hour of $\$ 23.67$, or 11 percent less than fulltime tenure track faculty, but 24 percent more than full-time non-tenure track faculty. Finally, the median part-time tenure track faculty earned $\$ 34.17$ per hour, or 29 percent more than fulltime tenure track faculty.

Of course, these differences in median earnings and earnings per hour ignore differences across the employment categories in the sector of higher education employment, field of specialization, and other individual and institutional attributes that may help to explain some of the differences in earnings between tenure track and non-tenure track, and full-time and part-time faculty. A quick examination of some of the summary measures by employment categories reveals some notable differences across faculty groups. Specifically, part-time tenure track faculty are significantly older than other faculty with an average age of almost 59 years old and 26 years of experience versus an average age of approximately 51 years old and 18 years of experience for full-time tenure track. It appears that many of the relatively few (3 percent) parttime tenure track faculty are likely to be in some form of phased retirement.

Both full-time and part-time non-tenure track faculty are much more likely to be women compared with tenure track faculty. While women account for about one third of the full-time tenure track faculty they represent 53 percent of full-time non-tenure track and 47 percent of part-time non-tenure track.

There are also differences across Carnegie classifications in the use of contingent faculty. In particular, while research universities account for 25 percent of all full-time tenure track faculty in the sample, they employ 32 percent of all full-time non-tenure track faculty and only 13 percent of all part-time non-tenure track faculty. Research universities may use fewer parttime non-tenure track faculty because they have a ready supply of graduate students available to 
do some of the teaching that might otherwise have been done by part-time faculty. Similarly, while two-year institutions account for 21 percent of all full-time tenure track faculty, 40 percent

of all part-time non-tenure track faculty are employed at two-year institutions. Specialized institutions (such as culinary institutions, and music schools) are more likely to employ part-time tenure track faculty than other types of institutions. Clearly there are differences in both individual characteristics and the type of institution of employment across the four faculty categories examined here. The following section controls for these individual and institutional attributes and isolates the employment contract earnings differentials conditional on these characteristics.

\section{Regression Results.}

The preceding summary measures revealed sizeable differences in the use of full-time and part-time non-tenure track, and part-time tenure track faculty across institutional type. Additionally, there may be significant differences in the relative compensation of part-time versus full-time and tenure track versus non-tenure track faculty across institutional type. The following regression estimates of earnings differentials across faculty employment categories are performed separately by Carnegie classification to allow for possible variation in earnings premia across institutional type. Table 4 presents the percentage differences in earnings across the contingent employment categories relative to full-time tenure track assistant professors, based on regressions of the natural log of various earnings measures on years of experience and its square, rank (associate, full professor), gender, race (Hispanic, African-American, Asian), field of teaching, and number of career publications in different media (refereed journals, non- 
refereed journals, books or chapters, book reviews, presentation, other scholarly output). ${ }^{5}$ Tests for error components due to multiple observations from the same institution did not find significant random effects in most cases and so OLS regression is used.

The first specifications of Table 4 show the percentage differences in basic institutional salary for full-time non-tenure track, part-time non-tenure track, and part-time tenure track relative to full-time tenure track assistant professors conditional on the regressors outlined above. Full-time non-tenure track faculty earned between 10 percent less at baccalaureate colleges (although this difference was not significantly different from zero at even the 10 percent level) to 24 percent less at comprehensive institutions, than full-time tenure track assistant professors. Part-time non-tenure track faculty earned an amazingly consistent 80 to 85 percent less across institutional type. On the other hand, part-time tenure track faculty earned between 49 percent less at doctoral universities to 77 percent less at specialized institutions, than full-time assistant professors.

Of course, differences in basic institutional salaries ignore differences in the expected work requirements across employment categories. The second regression results of Table 4 present the percentage differences in basic institutional salary per class section. While the earnings differentials per section are smaller the results are quite similar. Full-time non-tenure track faculty earn between 6 percent less at specialized institutions (not significantly different from zero) to 30 percent less at research universities, per class section. Part-time non-tenure track faculty earn between 60 percent less at two-year colleges to 70 percent less at research, doctoral, and specialized institutions. Part-time tenure track faculty earn between 7 percent less per section at baccalaureate colleges, although this difference is not significantly different from zero, to 62 percent less at specialized institutions.

${ }^{5}$ The percentage difference is calculated as $\exp (\beta)-1$. 
As mentioned above, tenure track faculty are usually responsible for not just teaching, but also for producing research and providing services to their institution. As a result, tenure track faculty earnings per class section actually overstates what they are being paid per section, as teaching only represents some portion of their job description. A better measure of earnings per unit of input is to examine earnings per hour of work. Table 4 shows the percentage differences in institutional salary per hour of paid institutional work. The institutional compensation per hour of full-time non-tenure track faculty at research universities, doctoral universities, baccalaureate colleges, and specialized institutions is not significantly different from the compensation per hour of full-time tenure track assistant professors. At comprehensive institutions and two-year colleges full-time non-tenure track faculty have average salaries per hour that are 13 and 20 percent less, respectively. Part-time non-tenure track faculty earn between 22 percent less per hour at research universities to 40 percent less at comprehensive and baccalaureate colleges. Part-time tenure track faculty at research universities earn 19 percent more than full-time tenure track assistant professors per hour, while part-time tenure track faculty at specialized institutions earn 25 percent less per hour.

An alternative examination of the remuneration of faculty measures total earnings from all sources and provides a more complete picture of the financial position of faculty based on their employment status within higher education. Total earnings of full-time non-tenure track faculty at research universities, baccalaureate colleges, two-year colleges, and specialized institutions are not significantly different from the total earnings of full-time tenure track assistant professors at those institutional types. Full-time non-tenure track faculty earn 15 and 16 percent less at doctoral, and comprehensive institutions, respectively. Additionally, part-time non-tenure track faculty earn between 32 and 46 percent less than comparable full-time tenure track assistant professors, and part-time tenure track faculty earn between 19 and 43 percent less. 
Finally, total earnings per hour provide a consistent metric with which to compare the earnings across employment categories. Full-time non-tenure track faculty at research, doctoral, baccalaureate, and specialized institutions have total earnings per hour that are not significantly different from full-time tenure track assistant professors, while faculty at comprehensive and two-year institutions earn 11 and 25 percent less, respectively. Part-time non-tenure track faculty at all institutional types have total earnings per hour that are not significantly different from full-time tenure track assistant professors, with the exception of two-year institutions where part-time non-tenure track faculty earn 9 percent more on average. Similarly, part-time tenure track faculty at research universities, comprehensive institutions, and specialized institutions actually earn significantly more per hour than full-time tenure track assistant professors, while the earnings per hour of part-time tenure track faculty at all other institutional types are not significantly different from full-time tenure track assistant professors.

The results of Table 4 suggest that while non-traditional faculty have institutional earnings that are significantly lower than the earnings of full-time tenure track faculty, these earnings differentials are dramatically reduced when one examines earnings per hour, and in particular total earnings from all sources per hour of paid work. Additionally, it is striking how similar the institutional earnings penalty is for being off the tenure track across institutional type. While there is a consistency in the effect of employment category on basic institutional salary across institutional type, there need not be the same returns to other individual and institutional characteristics across employment categories. To test for and allow for variation in the returns to individual and institutional attributes across employment categories separate regressions were run for full-time tenure track, full-time non-tenure track, and part-time non-tenure track. Parttime tenure track faculty are excluded from the following analysis as they represent too small a percentage of all faculty (3 percent) to perform a meaningful separate analysis. Additionally, as 
faculty are not randomly assigned to an employment category but rather choose and are chosen to work in a given contract it is necessary to correct for this selectivity. A multinomial logit is first performed across the three faculty categories and the results of this analysis are used to include an inverse Mills ratio among the regressors in the earnings equations. Marital status and number of children are used to identify the logit equation from the earnings equations (see Appendix A for multinomial logit results).

As most of the variation in hours is across employment categories, table 5 presents the results of the regression of the natural log of basic institutional salary on individual and institution attributes separately by employment category. Chow tests reject the null at the one percent level that the coefficients are the same for full-time non-tenure track and part-time nontenure track compared to full-time tenure track faculty.

There are a number of interesting differences in the returns across employment categories. For example, while full-time faculty, both tenure track and non-tenure track, have the usual concave experience profile of earnings, there are no significant returns to years of experience (years since highest degree) for part-time non-tenure track faculty. Additionally, there are no significant earnings differentials across gender. On the other hand, African-American and Asian full-time tenure track faculty receive a significant earnings premium.

It is also interesting to note that there is the expected public earnings penalty as found by Zoghi (2003) and Alexander (2001), but this penalty is even more pronounced for non-tenure track faculty. Similarly, while for full-time tenure track faculty there is approximately a 5 percent earnings advantage for working at an institution where the full-time faculty are represented by a union or collective bargaining agent (whether the individual is eligible and a member or not), this advantage is much larger for part-time non-tenure track faculty. Part-time 
non-tenure track faculty appear to gain from working at institutions where the full-time faculty are represented for collective bargaining, but full-time non-tenure track faculty do not.

The earnings differentials across Carnegie classification also vary a great deal across employment categories. The earnings differentials across institutional sectors are much more pronounced for non-tenure track faculty than they are for tenure track faculty. On the other hand, there are fewer significant differences in earnings across field of teaching for part-time faculty than for full-time faculty. Finally, the returns to an additional refereed journal article are greater for part-time faculty than for full-time faculty. This may be because the primary return for full-time tenure track faculty to publication is a promotion in rank, while for part-time faculty the return to publication is more direct.

Table 5 illustrates that there are significant differences in the returns to employment attributes across faculty status. In short, for part-time non-tenure track faculty where one works has a larger influence on one's earnings than one's individual characteristics, while for full-time faculty both individual and institutional affiliation are significant in determining earnings.

Using the returns to individual and institutional characteristics experienced by full-time tenure track faculty and applying them to the characteristics of non-tenure track faculty one is able to estimate what contingent faculty would have been paid had they been compensated in the same manner as tenure track faculty, given their attributes. Table 6A presents the regression results of the natural log of institutional salary per hour for full-time tenure track faculty. These regression coefficients are then applied to the characteristics of each of the full-time non-tenure track faculty and each of the part-time non-tenure track faculty. This allows for a comparison of the average difference in the predicted institutional salary per hour and the actual institutional salary per hour. Full-time non-tenure track faculty earned 25.9 percent less, and part-time non- 
tenure track faculty earned 64 percent less per hour on average from their institutions than would be predicted based on the returns of full-time tenure track assistant professors.

Table 6B presents the regression results for full-time tenure track faculty using total earnings from all sources per hour. Applying these coefficients to the non-tenure track faculty one is again able to estimate the earnings differentials between what contingent faculty earn per hour compared with what would be expected if they were treated the same as tenure track faculty. Full-time non-tenure track faculty earned 18.1 percent less, on average, than full-time tenure track assistant professors. On the other hand, part-time non-tenure track faculty earned only 1 percent less than would be expected if they were compensated in the same manner as fulltime tenure track assistant professors.

Clearly, full-time tenure track faculty are rewarded, at least in part, based on the quality of the outputs that they produce rather than just per unit of input. Unfortunately the data do not allow one to properly control for the quality of outputs (research, teaching, job and advanced degree placement of graduates), which almost certainly vary by employment category. While I attempt to control for selection into the various employment categories in the estimated earnings equations above, the inability to adequately control for output quality may render these attempts at selectivity correction less than complete. The above earnings differentials, therefore, should be viewed as the product of both differences in average output quality conditional on inputs (hours, research output) and differences due to employment status.

The above results suggest that non-tenure track faculty earn significantly less than tenure track faculty from their institutions. Particularly, part-time non-tenure track faculty earn much less from their institutions than full-time tenure track assistant professors even after controlling for the number of hours worked for the academic institution. The examination of total earnings per hour suggest that part-time faculty are foregoing significant earnings outside of their 
academic institution in order to work there. This suggests that there are non-pecuniary rewards or considerations among a substantial portion part-time non-tenure track faculty in their decision to work in academe.

\section{Conclusion}

There has been increased reliance on contingent faculty (part-time and full-time nontenure track) over the past 3 decades. The above analyses reveals that this increased utilization of contingent faculty is driven not just by the desire for greater long term employment flexibility realized by hiring faculty outside of the tenure system, but also affords institutions lower labor costs in the short-term, as well. Not surprisingly, full-time non-tenure track faculty and part-time non-tenure track faculty are remunerated much less than their full-time tenure track counterparts. Not only are contingent faculty paid less than traditional tenure track faculty, but they are paid less per class section and per hour by their institutions. Specifically, full-time non-tenure track faculty are paid 25.9 percent less, and part-time non-tenure track faculty are paid approximately 64 percent less per hour by their academic institution than comparable full-time tenure track assistant professors. On the other hand, total earnings from all sources per hour are much closer for tenure track and non-tenure track faculty. In fact, full-time non-tenure track faculty earned approximately 18 percent less than full-time tenure track assistant professors, while part-time non-tenure track faculty had total earnings per hour that were 1 percent lower than tenure track assistant professors. So while part-time non-tenure track faculty are paid significantly less and even significantly less per hour by their institution, their total earnings from all sources per hour are quite similar to the hourly earnings of full-time tenure track assistant professors. Clearly, many part-time non-tenure track faculty have employment profiles that provide them with earnings that are comparable to the hourly earnings profiles of tenure track faculty. On the other 
hand, full-time non-tenure track faculty salaries per hour, both from one's institution and overall, lag well behind the salaries of tenure track faculty.

These results suggest that many of these part-timers are willing to forego higher earnings outside of higher education for less generous compensation for teaching at a college or university. They must feel there are some non-pecuniary benefits or rewards for teaching. It may be this supply of willing part-timers with adequate outside compensation that helps to hold down the compensation of contingent faculty relative to tenure track faculty within higher education.

Efforts to address the employment and compensation concerns of contingent faculty should be cautious in suggesting policies that treat all part-time employees the same. The results of this analysis suggest that a significant percentage of part-time employees are willing to forego higher compensation outside of academia in order to work in higher education. On the other hand, full-time non-tenure track faculty have lower overall compensation per hour than comparable part-time faculty and the career paths and opportunities afforded to this group of contingent faculty warrants further investigation. Additionally, further analysis into the career paths of contingent faculty would provide an important insight into the long term financial and professional success of faculty off the tenure track. 


\section{References}

Alexander, King (2001). "The Silent Crisis: The Fiscal Capacity of Public Universities to Compete for Faculty." The Review of Higher Education, Winter, 2001.

Ehrenberg, Ronald, and Klaff, Daniel (2003) "Changes in Faculty Composition Within the State University of New York System: 1985 - 2001." Cornell Higher Education Research Institute, working paper number 38. August 2003.

Bell, Linda (2000). "More Good News, So Why the Blues?: The Annual Report on the Economic Status of the Profession, 1999-2000. Academe. March-April 2000.

Kosters, Marvin, and McCullough, Deirdre (1994). "Does Part-Time Work Pay.” The American Enterprise. November/December 1994. pp. 90-95.

Longmate, Jack, and Cosco, Frank (2002). "Part-Time Instructors Deserve Equal Pay for Equal Work.” Chronicle of Higher Education. May 3, 2002, online.

Lundy, Katherina, and Warme, Barbara (1992). "Gender and Career Trajectory: The Case of Part-Time Faculty.” in Working Part-Time. edited by Warme,B.D., Lundy, K.L., and Lundy, L.A., Praeger Publishers, New York, NY.

U.S. Bureau of Labor Statistics, Employment and Earnings, January issues 1973 to 1999.

U.S. Department of Education, National Center for Education Statistics, Integrated Postsecondary Education Data System (IPEDS), "Fall Staff Survey.” various years.

Zoghi, Cindy (2003). "Why Have Public University Professors Done So Badly?” Economics of Education Review. vol. 22(1) p. 45-57. 


\section{Table 1}

\section{Sample construction}

Total Sample

Faculty sampling weight not equal to zero

Faculty Status

Instructional Duties for Credit

Primary Activity is Teaching

Taught 1 to 12 Sections in Fall

Tenure System at Institution

Basic Salary $\$ 500$ to $\$ 300,000$

Usually Work More than 2 hours/week

Began Working for Institution Before 1998

Final Sample
18043

17608

16339

14946

11507

10999

9682

9617

9506

8274

8274

Faculty status; instructional duties for credit; principal activity is teaching; taught at least one class section in the fall but fewer than 12; tenure system at institution; basic salary from institution greater than $\$ 500$ and less than $\$ 300,000$; usual paid time from the institution greater than 2 hours per week; began at institution before 1998 (so that reported earnings are not for partial year). These restrictions result in a lower percentage of part-time faculty than in the fullweighted sample. The full weighted sample has 42.6 percent part-time, versus 39 percent parttime in this sample. 
Table 2

Summary Measures

\begin{tabular}{|c|c|c|c|c|}
\hline 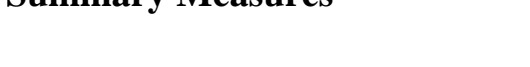 & Mean & Minimum & $\underline{\text { Maximum }}$ & $\underline{\text { Std. Deviation }}$ \\
\hline Full-time tenure track & 0.54 & 0.00 & 1.00 & 0.50 \\
\hline Full-time non-tenure track & 0.08 & 0.00 & 1.00 & 0.27 \\
\hline Part-time non-tenure track & 0.36 & 0.00 & 1.00 & 0.48 \\
\hline Part-time tenure track & 0.03 & 0.00 & 1.00 & 0.17 \\
\hline Assistant professor & 0.15 & 0.00 & 1.00 & 0.36 \\
\hline Associate professor & 0.19 & 0.00 & 1.00 & 0.39 \\
\hline Full professor & 0.25 & 0.00 & 1.00 & 0.43 \\
\hline Tenured & 0.44 & 0.00 & 1.00 & 0.50 \\
\hline Age & 50.41 & 25.00 & 83.00 & 10.11 \\
\hline Years of experience & 17.72 & 1.00 & 47.00 & 10.70 \\
\hline Years of seniority & 12.29 & 2.00 & 40.00 & 9.66 \\
\hline Male & 0.61 & 0.00 & 1.00 & 0.49 \\
\hline Hispanic & 0.04 & 0.00 & 1.00 & 0.18 \\
\hline African-American & 0.05 & 0.00 & 1.00 & 0.22 \\
\hline Asian & 0.04 & 0.00 & 1.00 & 0.21 \\
\hline Research university & 0.21 & 0.00 & 1.00 & 0.41 \\
\hline Doctoral university & 0.12 & 0.00 & 1.00 & 0.32 \\
\hline Comprehensive institution & 0.26 & 0.00 & 1.00 & 0.44 \\
\hline Baccalaureate college & 0.09 & 0.00 & 1.00 & 0.28 \\
\hline Two-year college & 0.27 & 0.00 & 1.00 & 0.44 \\
\hline Specialized institution & 0.06 & 0.00 & 1.00 & 0.24 \\
\hline Publicly controlled & 0.71 & 0.00 & 1.00 & 0.45 \\
\hline Union or collective bargaining & 0.46 & 0.00 & 1.00 & 0.50 \\
\hline Refereed journal articles & 9.74 & 0.00 & 200.00 & 23.67 \\
\hline Non-refereed journal articles & 6.36 & 0.00 & 175.00 & 18.45 \\
\hline Books and chapters & 2.32 & 0.00 & 64.00 & 7.35 \\
\hline Book reviews & 3.33 & 0.00 & 75.00 & 9.56 \\
\hline Presentations & 35.38 & 0.00 & 750.00 & 94.91 \\
\hline Other scholarly output & 0.34 & 0.00 & 15.00 & 1.63 \\
\hline Agriculture and natural resources & 0.02 & 0.00 & 1.00 & 0.13 \\
\hline Fine arts & 0.09 & 0.00 & 1.00 & 0.28 \\
\hline Business & 0.10 & 0.00 & 1.00 & 0.30 \\
\hline Computer science & 0.04 & 0.00 & 1.00 & 0.19 \\
\hline Education & 0.07 & 0.00 & 1.00 & 0.25 \\
\hline Engineering & 0.04 & 0.00 & 1.00 & 0.20 \\
\hline English & 0.10 & 0.00 & 1.00 & 0.30 \\
\hline Modern languages & 0.03 & 0.00 & 1.00 & 0.17 \\
\hline Health sciences & 0.09 & 0.00 & 1.00 & 0.28 \\
\hline Natural sciences & 0.09 & 0.00 & 1.00 & 0.28 \\
\hline Mathematics & 0.06 & 0.00 & 1.00 & 0.24 \\
\hline Psychology & 0.04 & 0.00 & 1.00 & 0.20 \\
\hline Other fields & 0.14 & 0.00 & 1.00 & 0.35 \\
\hline Social science & 0.10 & 0.00 & 1.00 & 0.30 \\
\hline
\end{tabular}


Table 3

Summary measures by faculty category

\begin{tabular}{|c|c|c|c|c|}
\hline Percent of Total & $\begin{array}{c}\begin{array}{c}\text { Full-time } \\
\text { tenure track }\end{array} \\
54 \%\end{array}$ & $\begin{array}{c}\begin{array}{c}\text { Full-time } \\
\text { Non-tenure track }\end{array} \\
8 \%\end{array}$ & $\begin{array}{c}\begin{array}{c}\text { Part-time } \\
\text { Non-Tenure track }\end{array} \\
\frac{36 \%}{}\end{array}$ & $\begin{array}{c}\begin{array}{c}\text { Part-time } \\
\text { Tenure track }\end{array} \\
3 \%\end{array}$ \\
\hline Professional time/week & 53.0 & 51.0 & 37.4 & 38.2 \\
\hline Paid time/week & 47.9 & 46.5 & 32.8 & 32.0 \\
\hline Inst. paid time/week & 45.5 & 42.0 & 13.6 & 22.0 \\
\hline \multicolumn{5}{|l|}{ Percent of time spent on: } \\
\hline Teaching & $66 \%$ & $72 \%$ & $62 \%$ & $70 \%$ \\
\hline Research & $13 \%$ & $6 \%$ & $4 \%$ & $9 \%$ \\
\hline Service & $14 \%$ & $12 \%$ & $8 \%$ & $9 \%$ \\
\hline Other & $7 \%$ & $9 \%$ & $26 \%$ & $12 \%$ \\
\hline \multicolumn{5}{|l|}{ Median earnings } \\
\hline Total earnings & $\$ 64,130$ & $\$ 45,652$ & $\$ 37,337$ & $\$ 50,848$ \\
\hline Total inst. earnings & $\$ 59,783$ & $\$ 41,304$ & $\$ 8,696$ & $\$ 21,739$ \\
\hline Basic inst. earnings & $\$ 54,978$ & $\$ 39,130$ & $\$ 7,826$ & $\$ 21,739$ \\
\hline Outside earnings & $\$ 272$ & $\$ 0$ & $\$ 22,011$ & $\$ 4,565$ \\
\hline $\begin{array}{l}\text { Ave. \# class } \\
\text { sections/year }\end{array}$ & 7.1 & 7.5 & 4.6 & 4.8 \\
\hline \multicolumn{5}{|l|}{$\underline{\text { Median earnings/input }}$} \\
\hline $\begin{array}{l}\text { Basic inst. } \\
\text { earning/section }\end{array}$ & $\$ 8,424$ & $\$ 5,435$ & $\$ 2,174$ & $\$ 5,435$ \\
\hline $\begin{array}{l}\text { Total inst earnings/(inst. } \\
\text { paid time/weekx52) }\end{array}$ & $\$ 26.13$ & $\$ 19.11$ & $\$ 15.68$ & $\$ 25.08$ \\
\hline $\begin{array}{l}\text { Total earnings/(total } \\
\text { paid time/weekx52) }\end{array}$ & $\$ 26.48$ & $\$ 19.11$ & $\$ 23.67$ & $\$ 34.17$ \\
\hline Age & 51.1 & 47.9 & 49.3 & 58.9 \\
\hline Years of experience & 18.4 & 14.1 & 16.7 & 26.1 \\
\hline Male & .67 & .47 & .53 & .71 \\
\hline Hispanic & .03 & .04 & .04 & .07 \\
\hline African-American & .05 & .06 & .05 & .04 \\
\hline Asian & .06 & .04 & .03 & .05 \\
\hline Research & .25 & .32 & .13 & .19 \\
\hline Doctoral & .12 & .19 & .10 & .11 \\
\hline Comprehensive & .27 & .24 & .23 & .25 \\
\hline Baccalaureate & .09 & .12 & .08 & .05 \\
\hline Two year & .21 & .09 & .40 & .26 \\
\hline Specialized & .06 & .04 & .06 & .14 \\
\hline Prefer part-time & & & .75 & .86 \\
\hline Full-time unavailable & & & .58 & .40 \\
\hline
\end{tabular}


Table 4

Percentage earnings differentials across faculty categories by institutional type

$\underline{\text { Research Doctoral Comprehensive }}$ Baccalaureate $\underline{\text { Two-year }}$ Specialized

Basic inst. salary

FT non-tenure trac

PT non-tenure track

PT tenure track

$\begin{array}{ccc}-0.20 * * * & -0.12 * * & -0.24 * * * \\ -0.80^{* * *} & -0.81 * * * & -0.85 * * * \\ -0.58 * * * & -0.49 * * * & -0.62 * * *\end{array}$

$-0.10$

$-0.83 * * *$

$-0.15$

$-0.16$

$-0.54 * * * \quad-0.68 * * * \quad-0.77 * * *$

Basic inst.

salary/section

FT non-tenure track

$-0.30 * * * \quad-0.21 * * *$

$-0.27 * * *$

$-0.07$

$-0.10$

$-0.06$

PT non-tenure track

$-0.70 * * * \quad-0.70 * * *$

$-0.69 * * *$

$-0.65 * * *$

$-0.60 * * *$

$-0.70 * * *$

PT tenure track

$-0.32 * * * \quad-0.34 * * *$

$-0.35 * * *$

$-0.07$

$-0.39 * * *$

$-0.62 * * *$

Inst. salary/hour

FT non-tenure track

$\begin{array}{ccc}-0.06 & 0.05 & -0.13^{* *} \\ -0.22 * * * & -0.28 * * * & -0.40 * * * \\ 0.19 * * & -0.16 & -0.12 *\end{array}$

$-0.07$

$-0.20 * *$

$-0.40 * * *$

$-0.35 * * *$

$-0.02$

PT non-tenure track

$0.19 * * \quad-0.16$

$-0.22$

$-0.20 * *$

$-0.27 * * *$

PT tenure track

Total earnings

FT non-tenure track

$\begin{array}{ccc}-0.07 & -0.15^{* *} & -0.16 * * * \\ -0.40^{* * *} & -0.42^{* * *} & -0.46^{* * *} \\ -0.33^{* * *} & -0.27 * * & -0.38^{* * *}\end{array}$

$-0.10$

$-0.36 * * *$

$-0.11$

0.07

PT non-tenure track

$-0.33 * * *$

$-0.43 * * *$

$-0.41 * * *$

$-0.32 * * *$

PT tenure track

Total earnings/hour

FT non-tenure track

PT non-tenure track

PT tenure track

$\begin{array}{ll}-0.02 & -0.07 \\ -0.01 & 0.01 \\ 0.32 * * & 0.16\end{array}$

$-0.11 *$

$-0.07$

$-0.25 * *$

0.02

$0.32 * *$

0.16

$-0.05$

0.08

$0.09 *$

0.07

$0.17^{*}$

$-0.21$

0.07

$0.36 * *$

Note:

Percentage difference in natural log of earnings relative to a tenure track assistant professor, conditional on years of experience and its square, rank, gender, race, field of teaching, and career publication output. $* * *(* *, *)$ indicates significantly different from zero at the $1 \%(5 \%, 10 \%)$ level. 
Table 5

Regression results by faculty category

Dependent variable is the natural log of basic institutional salary

\begin{tabular}{|c|c|c|c|c|c|c|c|c|c|c|c|c|c|}
\hline & $\begin{array}{l}\text { Full-time } \\
\text { tenure track }\end{array}$ & & $\begin{array}{l}\text { ull-Time } \\
\text {-tenure track }\end{array}$ & & $\begin{array}{l}\text { art-time } \\
\text { tenure track }\end{array}$ & & & $\begin{array}{l}\text { Full-time } \\
\text { tenure track }\end{array}$ & & $\begin{array}{c}\text { Full-Time } \\
\text { on-tenure track }\end{array}$ & & $\begin{array}{c}\text { Part-time } \\
\text { on-tenure track }\end{array}$ & \\
\hline Constant & $\begin{array}{l}10.594 \\
(0.079)\end{array}$ & $* * *$ & $\begin{array}{c}9.904 \\
(0.312)\end{array}$ & $* * *$ & $\begin{array}{c}9.054 \\
(0.177)\end{array}$ & $* * *$ & Agriculture & $\begin{array}{c}-0.006 \\
(0.33)\end{array}$ & & $\begin{array}{c}0.159 \\
(0.139)\end{array}$ & & $\begin{array}{l}-0.044 \\
(0.204)\end{array}$ & \\
\hline Associate & $\begin{array}{c}0.040 \\
(0.012)\end{array}$ & $* * *$ & ------- & & ------- & & Fine Arts & $\begin{array}{c}-0.079 \\
(0.021)\end{array}$ & $* * *$ & $\begin{array}{c}-0.200 \\
(0.136)\end{array}$ & & $\begin{array}{c}-0.192 \\
(0.094)\end{array}$ & $* *$ \\
\hline Professor & $\begin{array}{l}0.196 \\
(0.0)\end{array}$ & $* * *$ & ------- & & ------- & & Business & $\begin{array}{c}0.064 \\
(0.018)\end{array}$ & $* * *$ & $\begin{array}{c}0.126 \\
(0.091)\end{array}$ & * & $\begin{array}{l}-0.126 \\
(0.094)\end{array}$ & \\
\hline Ph.D. & $\begin{array}{c}0.171 \\
(0.036)\end{array}$ & $* * *$ & $\begin{array}{l}-0.135 \\
(0.203)\end{array}$ & & $\begin{array}{l}-0.266 \\
(0.182)\end{array}$ & & Computers Sci. & $\begin{array}{c}0.085 \\
(0.026)\end{array}$ & $* * *$ & $\begin{array}{c}0.109 \\
(0.124)\end{array}$ & & $\begin{array}{c}0.040 \\
(0.116)\end{array}$ & \\
\hline Experience & $\begin{array}{c}0.011 \\
(0.002)\end{array}$ & $* * *$ & $\begin{array}{c}0.009 \\
(0.005)\end{array}$ & $*$ & $\begin{array}{l}-0.0114 \\
(0.009)\end{array}$ & & Education & $\begin{array}{l}-0.068 \\
(0.020)\end{array}$ & $* *$ & $\begin{array}{l}-0.044 \\
(0.099)\end{array}$ & & $\begin{array}{l}-0.116 \\
(0.102)\end{array}$ & \\
\hline Exp. Squared & $\begin{array}{l}-0.00007 \\
(0.0004)\end{array}$ & & $\begin{array}{l}-0.0004 \\
(0.0002)\end{array}$ & $* *$ & $\begin{array}{c}0.0003 \\
(0.0002)\end{array}$ & & Engineering & $\begin{array}{c}0.060 \\
(0.023)\end{array}$ & $* *$ & $\begin{array}{c}0.215 \\
(0.128)\end{array}$ & * & $\begin{array}{l}-0.156 \\
(0.148)\end{array}$ & \\
\hline Male & $\begin{array}{c}0.016 \\
(0.010)\end{array}$ & & $\begin{array}{c}0.024 \\
(0.046)\end{array}$ & & $\begin{array}{c}0.012 \\
(0.042)\end{array}$ & & English & $\begin{array}{c}-0.101 \\
(0.020)\end{array}$ & $* * *$ & $\begin{array}{c}-0.031 \\
(0.105)\end{array}$ & & $\begin{array}{c}0.101 \\
(0.090)\end{array}$ & \\
\hline Hispanic & $\begin{array}{c}0.030 \\
(0.024)\end{array}$ & & $\begin{array}{c}0.061 \\
(0.097)\end{array}$ & & $\begin{array}{c}0.056 \\
(0.106)\end{array}$ & & Languages & $\begin{array}{l}-0.047 \\
(0.027)\end{array}$ & & $\begin{array}{c}0.007 \\
(0.157)\end{array}$ & & $\begin{array}{c}0.008 \\
(0.139)\end{array}$ & \\
\hline Afr.-Amer. & $\begin{array}{c}0.034 \\
(0.019)\end{array}$ & $*$ & $\begin{array}{c}0.063 \\
(0.070)\end{array}$ & & $\begin{array}{l}-0.029 \\
(0.092)\end{array}$ & & Health Sci. & $\begin{array}{c}0.036 \\
(0.020)\end{array}$ & $*$ & $\begin{array}{c}0.512 \\
(0.141)\end{array}$ & $* * *$ & $\begin{array}{c}-0.070 \\
(0.113)\end{array}$ & \\
\hline Asian & $\begin{array}{c}0.052 \\
(0.018)\end{array}$ & $* * *$ & $\begin{array}{c}0.103 \\
(0.010)\end{array}$ & & $\begin{array}{c}0.033 \\
(0.118)\end{array}$ & & Natural Sci. & $\begin{array}{l}-0.057 \\
(0.017)\end{array}$ & $* * *$ & $\begin{array}{c}0.102 \\
(0.130)\end{array}$ & & $\begin{array}{l}-0.242 \\
(0.126)\end{array}$ & $*$ \\
\hline Public & $\begin{array}{c}-0.049 \\
(0.014)\end{array}$ & $* * *$ & $\begin{array}{c}-0.112 \\
(0.048)\end{array}$ & $* *$ & $\begin{array}{c}-0.210 \\
(0.100)\end{array}$ & $* *$ & Mathematics & $\begin{array}{c}-0.035 \\
(0.020)\end{array}$ & $*$ & $\begin{array}{c}-0.053 \\
(0.111)\end{array}$ & & $\begin{array}{c}-0.066 \\
(0.103)\end{array}$ & \\
\hline Unionized & $\begin{array}{c}0.054 \\
(0.009)\end{array}$ & $* * *$ & $\begin{array}{l}-0.035 \\
(0.064)\end{array}$ & & $\begin{array}{c}0.168 \\
(0.042)\end{array}$ & $* * *$ & Psychology & $\begin{array}{l}-0.077 \\
(0.025)\end{array}$ & $* * *$ & $\begin{array}{l}-0.236 \\
(0.130)\end{array}$ & $*$ & $\begin{array}{c}0.043 \\
(0.119)\end{array}$ & \\
\hline Doctoral & $\begin{array}{c}-0.073 \\
(0.014)\end{array}$ & $* * *$ & $\begin{array}{c}-0.113 \\
(0.061)\end{array}$ & $*$ & $\begin{array}{l}-0.190 \\
(0.084)\end{array}$ & $* *$ & Other Fields & $\begin{array}{c}-0.003 \\
(0.017)\end{array}$ & & $\begin{array}{c}0.220 \\
(0.098)\end{array}$ & $* *$ & $\begin{array}{c}-0.231 \\
(0.083)\end{array}$ & $* * *$ \\
\hline Comprehensive & $\begin{array}{c}-0.123 \\
(0.014)\end{array}$ & $* * *$ & $\begin{array}{c}-0.371 \\
(0.148)\end{array}$ & $* *$ & $\begin{array}{l}-0.420 \\
(0.072)\end{array}$ & $* * *$ & Refereed Artl. & $\begin{array}{c}0.002 \\
(0.0002)\end{array}$ & $* * *$ & $\begin{array}{c}-0.005 \\
(0.003)\end{array}$ & & $\begin{array}{c}0.004 \\
(0.003)\end{array}$ & \\
\hline Baccalaureate & $\begin{array}{c}-0.210 \\
(0.022)\end{array}$ & $* * *$ & $\begin{array}{c}-0.346 \\
(0.132)\end{array}$ & $* * *$ & $\begin{array}{c}-0.518 \\
(0.113)\end{array}$ & $* * *$ & Non-ref. Artl. & $\begin{array}{c}0.0005 \\
(0.0002)\end{array}$ & $* *$ & $\begin{array}{c}0.001 \\
(0.001)\end{array}$ & & $\begin{array}{c}-0.002 \\
(0.001)\end{array}$ & \\
\hline Two-year & $\begin{array}{l}-0.106 \\
(0.019)\end{array}$ & $* * *$ & $\begin{array}{l}-0.760 \\
(0.377)\end{array}$ & $* *$ & $\begin{array}{l}-0.268 \\
(0.080)\end{array}$ & $* * *$ & Books/chapts. & $\begin{array}{c}0.0003 \\
(0.0006)\end{array}$ & & $\begin{array}{l}-0.001 \\
(0.003)\end{array}$ & & $\begin{array}{c}0.002 \\
(0.003)\end{array}$ & \\
\hline \multirow[t]{2}{*}{ Specialized } & $\begin{array}{c}-0.176 \\
(0.021)\end{array}$ & $* * *$ & $\begin{array}{l}-0.466 \\
(0.233)\end{array}$ & $* *$ & $\begin{array}{l}-0.272 \\
(0.096)\end{array}$ & $* * *$ & Book Reviews & $\begin{array}{c}0.001 \\
(0.0005)\end{array}$ & $* * *$ & $\begin{array}{l}-0.0006 \\
(0.005)\end{array}$ & & $\begin{array}{l}-0.004 \\
(0.004)\end{array}$ & \\
\hline & & & & & & & Presentations & $\begin{array}{c}0.0002 \\
(0.0001)\end{array}$ & $* *$ & $\begin{array}{c}0.0002 \\
(0.0002)\end{array}$ & & $\begin{array}{c}0.0001 \\
(0.0002)\end{array}$ & \\
\hline R-squared & 0.37 & & 0.23 & & 0.07 & & Other Scholar & $\begin{array}{l}-0.003 \\
(0.003)\end{array}$ & & $\begin{array}{c}0.022 \\
(0.011)\end{array}$ & $*$ & $\begin{array}{l}-0.012 \\
(0.014)\end{array}$ & \\
\hline Chow test & & & 8.17 & & 365.94 & & Lambda & $\begin{array}{c}0.076 \\
(0.055)\end{array}$ & & $\begin{array}{c}.586 \\
(0.033)\end{array}$ & $*$ & $\begin{array}{c}0.450 \\
(0.266)\end{array}$ & * \\
\hline
\end{tabular}


Table 6A

Regression results for full-time tenure track faculty

Dependent variable is the natural log of total institutional salary per institutional hour

\begin{tabular}{|c|c|c|c|c|c|}
\hline Constant & $\begin{array}{c}2.700 \\
(0.110)\end{array}$ & $* * *$ & Agriculture & $\begin{array}{l}-0.039 \\
(0.045)\end{array}$ & \\
\hline Associate & $\begin{array}{c}0.014 \\
(0.003)\end{array}$ & $* * *$ & Fine Arts & $\begin{array}{c}0.021 \\
(0.029)\end{array}$ & \\
\hline Professor & $\begin{array}{c}-0.0001 \\
(0.00006)\end{array}$ & $*$ & Business & $\begin{array}{c}0.157 \\
(0.025)\end{array}$ & $* * *$ \\
\hline Ph.D. & $\begin{array}{c}0.055 \\
(0.014)\end{array}$ & $* * *$ & Computers Sci. & $\begin{array}{c}0.048 \\
(0.036)\end{array}$ & \\
\hline Experience & $\begin{array}{c}0.201 \\
(0.018)\end{array}$ & $* * *$ & Education & $\begin{array}{c}-0.006 \\
(0.028)\end{array}$ & \\
\hline Exp. Squared & $\begin{array}{c}0.212 \\
(0.050)\end{array}$ & $* * *$ & Engineering & $\begin{array}{c}0.065 \\
(0.032)\end{array}$ & $* *$ \\
\hline Male & $\begin{array}{c}0.057 \\
(0.014)\end{array}$ & $* * *$ & English & $\begin{array}{c}-0.111 \\
(0.027)\end{array}$ & $* * *$ \\
\hline Hispanic & $\begin{array}{c}0.107 \\
(0.033)\end{array}$ & $* * *$ & Languages & $\begin{array}{c}0.001 \\
(0.038)\end{array}$ & \\
\hline Afr.-Amer. & $\begin{array}{c}0.189 \\
(0.026)\end{array}$ & $* * *$ & Health Sci. & $\begin{array}{c}0.054 \\
(0.027)\end{array}$ & $* *$ \\
\hline Asian & $\begin{array}{c}0.142 \\
(0.026)\end{array}$ & $* * *$ & Natural Sci. & $\begin{array}{l}-0.121 \\
(0.024)\end{array}$ & $* * *$ \\
\hline Public & $\begin{array}{l}-0.107 \\
(0.020)\end{array}$ & $* * *$ & Mathematics & $\begin{array}{c}-0.016 \\
(0.028)\end{array}$ & \\
\hline Unionized & $\begin{array}{c}0.101 \\
(0.013)\end{array}$ & $* * *$ & Psychology & $\begin{array}{c}-0.056 \\
(0.035)\end{array}$ & \\
\hline Doctoral & $\begin{array}{l}-0.067 \\
(0.020)\end{array}$ & $* * *$ & Other Fields & $\begin{array}{c}0.035 \\
(0.024)\end{array}$ & \\
\hline Comprehensive & $\begin{array}{c}-0.056 \\
(0.020)\end{array}$ & $* * *$ & Refereed Article & $\begin{array}{c}0.0018 \\
(0.0003)\end{array}$ & $* * *$ \\
\hline Baccalaureate & $\begin{array}{c}-0.224 \\
(0.031)\end{array}$ & $* * *$ & Non-ref. Artl. & $\begin{array}{c}0.0010 \\
(0.0003)\end{array}$ & $* * *$ \\
\hline Two-year & $\begin{array}{c}0.110 \\
(0.027)\end{array}$ & $* * *$ & Books/chapters & $\begin{array}{c}-0.0004 \\
(0.0008)\end{array}$ & \\
\hline \multirow[t]{2}{*}{ Specialized } & $\begin{array}{l}-0.102 \\
(0.029)\end{array}$ & $* * *$ & Book Reviews & $\begin{array}{c}0.0010 \\
(0.0006)\end{array}$ & \\
\hline & & & Presentations & $\begin{array}{c}0.0001 \\
(0.0001)\end{array}$ & \\
\hline Full-time non-tenure track & $25.9 \%$ & & Other Scholarly & $\begin{array}{l}0.0008 \\
(0.003)\end{array}$ & \\
\hline Part-time non-tenure track & $64.0 \%$ & & Lambda & $\begin{array}{c}0.197 \\
(0.077)\end{array}$ & $* *$ \\
\hline
\end{tabular}


Table 6B

Regression results for full-time tenure track faculty

Dependent variable is the natural log of total earnings per hour

\begin{tabular}{|c|c|c|c|c|}
\hline Constant & $\begin{array}{c}2.811 \\
(0.108)\end{array}$ & $* * *$ & Agriculture & $\begin{array}{l}-0.049 \\
(0.045)\end{array}$ \\
\hline Associate & $\begin{array}{c}0.014 \\
(0.002)\end{array}$ & $* * *$ & Fine Arts & $\begin{array}{c}-0.021 \\
(0.029)\end{array}$ \\
\hline Professor & $\begin{array}{c}-0.0001 \\
(0.00006)\end{array}$ & $*$ & Business & $\begin{array}{c}0.148 \\
(0.025)\end{array}$ \\
\hline Ph.D. & $\begin{array}{c}0.040 \\
(0.016)\end{array}$ & $* *$ & Computers Sci. & $\begin{array}{c}0.065 \\
(0.036)\end{array}$ \\
\hline Experience & $\begin{array}{c}0.180 \\
(0.018)\end{array}$ & $* * *$ & Education & $\begin{array}{l}-0.012 \\
(0.028)\end{array}$ \\
\hline Exp. Squared & $\begin{array}{c}0.177 \\
(0.049)\end{array}$ & $* * *$ & Engineering & $\begin{array}{c}0.062 \\
(0.032)\end{array}$ \\
\hline Male & $\begin{array}{c}0.062 \\
(0.013)\end{array}$ & $* * *$ & English & $\begin{array}{l}-0.123 \\
(0.027)\end{array}$ \\
\hline Hispanic & $\begin{array}{c}0.101 \\
(0.032)\end{array}$ & $* *$ & Languages & $\begin{array}{l}-0.007 \\
(0.037)\end{array}$ \\
\hline Afr.-Amer. & $\begin{array}{c}0.178 \\
(0.026)\end{array}$ & $* * *$ & Health Sci. & $\begin{array}{c}0.076 \\
(0.027)\end{array}$ \\
\hline Asian & $\begin{array}{c}0.131 \\
(0.025)\end{array}$ & $* * *$ & Natural Sci. & $\begin{array}{l}-0.130 \\
(0.024)\end{array}$ \\
\hline Public & $\begin{array}{l}-0.124 \\
(0.019)\end{array}$ & $* * *$ & Mathematics & $\begin{array}{l}-0.037 \\
(0.028)\end{array}$ \\
\hline Unionized & $\begin{array}{c}0.100 \\
(0.013)\end{array}$ & $* * *$ & Psychology & $\begin{array}{l}-0.042 \\
(0.035)\end{array}$ \\
\hline Doctoral & $\begin{array}{l}-0.072 \\
(0.020)\end{array}$ & $* * *$ & Other Fields & $\begin{array}{c}0.033 \\
(0.024)\end{array}$ \\
\hline Comprehensive & $\begin{array}{l}-0.081 \\
(0.019)\end{array}$ & $* * *$ & Refereed Article & $\begin{array}{c}0.0019 \\
(0.0003)\end{array}$ \\
\hline Baccalaureate & $\begin{array}{l}-0.255 \\
(0.030)\end{array}$ & $* * *$ & Non-ref. Artl. & $\begin{array}{c}0.0010 \\
(0.0003)\end{array}$ \\
\hline Two-year & $\begin{array}{c}0.093 \\
(0.026)\end{array}$ & $* * *$ & Books/chapters & $\begin{array}{c}0.0003 \\
(0.0008)\end{array}$ \\
\hline \multirow[t]{2}{*}{ Specialized } & \multirow[t]{2}{*}{$\begin{array}{l}-0.109 \\
(0.029)\end{array}$} & \multirow[t]{2}{*}{$* * *$} & Book Reviews & $\begin{array}{c}0.0007 \\
(0.0006)\end{array}$ \\
\hline & & & Presentations & $\begin{array}{c}0.0001 \\
(0.0001)\end{array}$ \\
\hline Full-time non-tenure track & \multicolumn{2}{|l|}{$18.1 \%$} & Other Scholarly & $\begin{array}{c}0.0037 \\
(0.003)\end{array}$ \\
\hline Part-time non-tenure track & $1.0 \%$ & & Lambda & $\begin{array}{c}0.127 \\
(0.076)\end{array}$ \\
\hline
\end{tabular}




\begin{tabular}{|c|c|c|c|c|c|c|c|c|c|}
\hline \multicolumn{10}{|c|}{ Appendix A: Multinomial Lo } \\
\hline \multirow{2}{*}{ Constant } & \multicolumn{2}{|c|}{$\begin{array}{c}\text { Full-time } \\
\text { non-tenure track }\end{array}$} & \multicolumn{2}{|c|}{$\begin{array}{c}\text { Part-time } \\
\text { non-tenure track }\end{array}$} & \multirow[b]{2}{*}{ Agriculture } & \multirow{2}{*}{\multicolumn{2}{|c|}{$\begin{array}{c}\begin{array}{c}\text { Full-time } \\
\text { non-tenure track }\end{array} \\
-0.505 \\
(0.374)\end{array}$}} & \multicolumn{2}{|c|}{$\begin{array}{c}\text { Part-time } \\
\text { non-tenure track }\end{array}$} \\
\hline & $\begin{array}{c}1.201 \\
(0.250)\end{array}$ & $* * *$ & $\begin{array}{c}1.484 \\
(0.178)\end{array}$ & $* * *$ & & & & $\begin{array}{l}-0.942 \\
(0.276)\end{array}$ & $* *$ \\
\hline Experience & $\begin{array}{l}-0.039 \\
(0.016)\end{array}$ & $* *$ & $\begin{array}{l}-0.071 \\
(0.010)\end{array}$ & $* * *$ & Fine Arts & $\begin{array}{l}-0.829 \\
(2.450)\end{array}$ & $* *$ & $\begin{array}{l}-0.307 \\
(0.142)\end{array}$ & \\
\hline Experience squared & $\begin{array}{l}-0.0001 \\
(0.0004)\end{array}$ & & $\begin{array}{c}0.0015 \\
(0.0003)\end{array}$ & $* * *$ & Business & $\begin{array}{c}0.155 \\
(0.203)\end{array}$ & & $\begin{array}{l}-0.234 \\
(0.132)\end{array}$ & $*$ \\
\hline Ph.D. & $\begin{array}{l}-2.109 \\
(0.104)\end{array}$ & $* * *$ & $\begin{array}{l}-1.910 \\
(0.075)\end{array}$ & $* * *$ & Computers Sci. & $\begin{array}{c}0.227 \\
(0.290)\end{array}$ & & $\begin{array}{l}-0.083 \\
(0.179)\end{array}$ & \\
\hline Male & $\begin{array}{l}-0.189 \\
(0.094)\end{array}$ & $* *$ & $\begin{array}{l}-0.012 \\
(0.065)\end{array}$ & & Education & $\begin{array}{c}0.358 \\
(0.218)\end{array}$ & & $\begin{array}{c}0.161 \\
(0.143)\end{array}$ & \\
\hline Hispanic & $\begin{array}{l}-0.178 \\
(0.020)\end{array}$ & & $\begin{array}{c}0.045 \\
(0.128)\end{array}$ & & Engineering & $\begin{array}{l}-0.223 \\
(0.300)\end{array}$ & & $\begin{array}{l}-0.477 \\
(0.197)\end{array}$ & $* *$ \\
\hline African-American & $\begin{array}{l}-0.022 \\
(0.152)\end{array}$ & & $\begin{array}{l}-0.216 \\
(0.113)\end{array}$ & * & English & $\begin{array}{c}0.612 \\
(0.204)\end{array}$ & $* * *$ & $\begin{array}{c}0.288 \\
(0.131)\end{array}$ & $* *$ \\
\hline Asian & $\begin{array}{l}-0.338 \\
(0.209)\end{array}$ & & $\begin{array}{l}-0.122 \\
(0.142)\end{array}$ & & Languages & $\begin{array}{c}0.827 \\
(0.247)\end{array}$ & $* * *$ & $\begin{array}{c}0.007 \\
(0.185)\end{array}$ & \\
\hline Public & $\begin{array}{l}-0.210 \\
(0.111)\end{array}$ & $*$ & $\begin{array}{l}-0.758 \\
(0.008)\end{array}$ & $* * *$ & Health Sci. & $\begin{array}{c}0.725 \\
(0.195)\end{array}$ & $* * *$ & $\begin{array}{c}-0.414 \\
(0.142)\end{array}$ & $* * *$ \\
\hline Unionized & $\begin{array}{l}-0.354 \\
(0.092)\end{array}$ & $* * *$ & $\begin{array}{c}0.022 \\
(0.063)\end{array}$ & & Natural Sci. & $\begin{array}{c}0.595 \\
(0.215)\end{array}$ & $* * *$ & $\begin{array}{l}-0.368 \\
(0.150)\end{array}$ & $* *$ \\
\hline Doctoral & $\begin{array}{l}-0.233 \\
(0.132)\end{array}$ & $*$ & $\begin{array}{c}0.077 \\
(0.117)\end{array}$ & & Mathematics & $\begin{array}{c}0.220 \\
(0.243)\end{array}$ & & $\begin{array}{l}-0.127 \\
(0.151)\end{array}$ & \\
\hline Comprehensive & $\begin{array}{l}-1.160 \\
(0.120)\end{array}$ & $* * *$ & $\begin{array}{l}-0.391 \\
(0.010)\end{array}$ & $* * *$ & Psychology & $\begin{array}{c}0.153 \\
(0.320)\end{array}$ & & $\begin{array}{c}0.460 \\
(0.175)\end{array}$ & $* * *$ \\
\hline Baccalaureate & $\begin{array}{l}-1.156 \\
(0.183)\end{array}$ & $* * *$ & $\begin{array}{c}-0.776 \\
(0.145)\end{array}$ & $* * *$ & Other Fields & $\begin{array}{c}0.501 \\
(0.195)\end{array}$ & $* * *$ & $\begin{array}{c}0.186 \\
(0.124)\end{array}$ & \\
\hline Two-year & $\begin{array}{l}-2.809 \\
(0.166)\end{array}$ & $* * *$ & $\begin{array}{l}-0.219 \\
(0.108)\end{array}$ & $* *$ & Refereed Article & $\begin{array}{l}-0.027 \\
(0.005)\end{array}$ & $* * *$ & $\begin{array}{l}-0.002 \\
(0.003)\end{array}$ & $* * *$ \\
\hline \multirow[t]{7}{*}{ Specialized } & $\begin{array}{l}-1.583 \\
(0.220)\end{array}$ & $* * *$ & $\begin{array}{c}-0.133 \\
(0.146)\end{array}$ & & Non-ref. Artl. & $\begin{array}{l}-0.002 \\
(0.004)\end{array}$ & & $\begin{array}{c}0.002 \\
(0.002)\end{array}$ & \\
\hline & & & & & Books/chapters & $\begin{array}{c}0.007 \\
(0.007)\end{array}$ & $*$ & $\begin{array}{c}0.003 \\
(0.005)\end{array}$ & \\
\hline & & & & & Book Reviews & $\begin{array}{l}-0.028 \\
(0.009)\end{array}$ & $* * *$ & $\begin{array}{l}-0.018 \\
(0.005)\end{array}$ & $* * *$ \\
\hline & & & & & Presentations & $\begin{array}{l}-0.0001 \\
(0.001)\end{array}$ & & $\begin{array}{c}0.001 \\
(0.0004)\end{array}$ & \\
\hline & & & & & Other Scholarly & $\begin{array}{c}0.034 \\
(0.030)\end{array}$ & & $\begin{array}{c}0.031 \\
(0.020)\end{array}$ & \\
\hline & & & & & Married & $\begin{array}{l}-0.011 \\
(0.103)\end{array}$ & & $\begin{array}{c}0.174 \\
(0.070)\end{array}$ & $* *$ \\
\hline & & & & & No. of Children & $\begin{array}{l}-0.015 \\
(0.035)\end{array}$ & & $\begin{array}{l}-0.020 \\
(0.024)\end{array}$ & \\
\hline
\end{tabular}

